\title{
Experimental studies of intermediate pyrolysis of woody and agricultural biomass in a fixed bed reactor
}

\author{
Artur Bieniek ${ }^{1}$, Wojciech Jerzak ${ }^{1}$, and Aneta Magdziarz ${ }^{1}$ \\ ${ }^{1}$ AGH University of Science and Technology, Mickiewicza 30 Av., 30-059 Cracow, Poland
}

\begin{abstract}
Biomass pyrolysis is an advanced process which leads to obtaining products as chars, primary tars and gases. Depending on pyrolysis conditions and reactor construction, the pyrolysis could be divided into three categories: slow, intermediate and fast. This work concerns the experimental analysis of an intermediate pyrolysis of biomass residues in a fixed bed reactor. As raw materials, pine bark and wheat straw were selected. Experiments were carried out at three temperatures: 400,500 and $600{ }^{\circ} \mathrm{C}$ under constant volume flow rate of inert gas equal to $100 \mathrm{ml} / \mathrm{min}$. Biomass samples were kept for 150 seconds in the hot zone. The main goal was to compare yields, elemental composition, and calorific values of received products under studied process conditions. The ultimate analysis of chars and organic fractions of oils was performed. Obtained results from ultimate analysis allowed to determine higher heating values by a theoretical correlation. The products of pyrolysis obtained at $600{ }^{\circ} \mathrm{C}$ characterized by the most energetic parameters. The higher heating value for organic fraction of tars was $31.62 \mathrm{MJ} / \mathrm{kg}$ while for char was $29.47 \mathrm{MJ} / \mathrm{kg}$.
\end{abstract}

\section{Introduction}

As a member of the European Union, Poland signed an agreement where had been obligated to increase the amount of renewable sources in the power engineering sector up to $15 \%$ until 2020 [1]. In Poland, by the end of 2019 the total share of renewable energy in primary energy production was only $11.4 \%$ [2]. The highest impact had wind energy with $65 \%$ share. The second place took biomass and biogas installations which had $19 \%$ of total share in renewable energy sources. This source has the biggest chance to increase its amount in renewable energy due to the high potential in biomass supply. In 2018, the Polish governmental institution of forest management reported that forest area of Poland refers to $29.6 \%$ of total land size and this amount is still increasing [3]. It places Poland in the leading position among European countries. Another $60 \%$ of Polish land is agricultural land where $40 \%$ is arable [4]. It shows that Poland is a country which has widely and common access to biomass from various sources. This fact could be used to satisfy requirements from the European Union where biomass content in primary energy demand would be increased.

Nowadays, biomass is the most frequently combusted or co-combusted with other solid fuels such as e.g. coal or lignite. Heat from exothermic reactions is used to produce primary energy. This method has been known from ages and this is the most developed technology to convert biomass feedstock. Other techniques of biomass usage are thermal conversion methods such as pyrolysis and gasification. In pyrolysis, long structures of basic compounds such as cellulose, hemicellulose and lignin are degraded at high temperature under non-oxidized atmosphere. Volatile matter included in raw biomass is released. The solid fraction, which remains after pyrolysis, is called a biochar. If biochar stays longer in the reactor and carbon dioxide or steam is used as inert gas, biochar starts to react with this gas. This process is named gasification. Pyrolysis and gasification supply products which are classified to three groups: char, condensable fraction of volatile matter, and non condensable gases. Gasification is mainly focused on delivering gaseous products while yield of products from pyrolysis is strongly dependent on the type of pyrolysis. Operating conditions used in pyrolysis categorize this process into several groups as slow, intermediate, fast [5]. The characterization of pyrolysis has been presented in Table 1.

Table 1. Classification of pyrolysis [5]

\begin{tabular}{|c|c|c|c|}
\hline Pyrolysis & Slow & $\begin{array}{c}\text { Inter } \\
\text { mediate }\end{array}$ & Fast \\
\hline $\begin{array}{c}\text { Temperature } \\
\left({ }^{\circ} \mathrm{C}\right)\end{array}$ & $\begin{array}{c}550- \\
950\end{array}$ & $\begin{array}{c}500- \\
650\end{array}$ & $\begin{array}{c}850- \\
1250\end{array}$ \\
\hline $\begin{array}{c}\text { Heating rate } \\
\left({ }^{\circ} \mathrm{C} / \mathrm{s}\right)\end{array}$ & $\begin{array}{c}0.1- \\
1\end{array}$ & $1-10$ & $\begin{array}{c}10- \\
200\end{array}$ \\
\hline $\begin{array}{c}\text { Residence } \\
\text { time (s) }\end{array}$ & $\begin{array}{c}300- \\
500\end{array}$ & $0.5-20$ & $<10$ \\
\hline
\end{tabular}

The slow pyrolysis delivers mainly char due to long residence time of biomass sample and released volatile matter [5-7]. Hot vapour is heated longer and secondary reactions start to dominate what leads to thermal cracking of primary tars. From the other side, fast pyrolysis is focused on production liquid fraction $[8,9]$.

${ }^{1}$ Corresponding author: artbie@agh.edu.pl 
Primary tars are kept in the hot zone as short as possible to prevent thermal cracking. The intermediate pyrolysis undergoes to obtain a balance between concentration of products. In works $[10,11]$, detailed investigations were conducted toward the determination of yields from various biomass feedstocks. Additionally, some authors show a method to improve this process mainly due to utilization of catalysts, especially zeolites [12,13].

The potential of utilization of biomass samples as pine bark and wheat straw had been investigated in works [7,14-16]. Greco et al. [7] analysed a slow pyrolysis of wheat straw in a fixed bed reactor at 300 , 350,400 and $450{ }^{\circ} \mathrm{C}$. Scientists reported that higher temperatures caused higher concentration of permanent gas from 31.4 to $38.4 \%$ while liquid fraction decreased from 32.5 to $29.2 \%$. The char also decreased from 36.1 to $32.4 \%$ as temperature was increasing. Lazdovica et al. [14] conducted experiments of intermediate and fast pyrolysis of wheat straw. Researchers used temperatures range from 250 to $700^{\circ} \mathrm{C}$ with heating rate from 60 to $100^{\circ} \mathrm{C} / \mathrm{min}$. Received oil content were from 5.1 to $74.4 \%$ respectively from 250 to $700^{\circ} \mathrm{C}$. Wang et al. [15] made an analysis of co - pyrolysis of pine bark and waste tires in a fixed bed reactor at $900{ }^{\circ} \mathrm{C}$. Scientists proved that increasing amount of pine bark caused higher concentration of carbon monoxide and hydrogen in the gas fraction. At the same time the concentration of heavy hydrocarbons decreased which led to obtaining a better quality oil. Güngör et al. [16] used a pine bark in two - step catalysed slow pyrolysis in a fixed bed reactor at 300, 400, 500 and $600{ }^{\circ} \mathrm{C}$. ZSM-5 and ReUS$\mathrm{Y}$ were involved as catalysts. Scientists proved that using these catalysts caused lowering oxygen content in oil fraction.

This paper concerns the possibility of producing fuel from pine bark and wheat straw via intermediate pyrolysis in a fixed bed reactor at three temperatures: 400,500 and $600^{\circ} \mathrm{C}$. Selected feedstocks were wastes from the agricultural and wood industry. The main goal was comparative analysis of quantity and quality of received products from every respected case. For received fuels ultimate analysis had been performed and then higher heating value was calculated. This value allows to determine the most calorific product from considered cases.

\section{$2 \quad$ Materials and methods}

\section{$2.1 \quad$ Laboratory setup}

This paper presents investigations of intermediate pyrolysis of two kinds of biomass in a fixed bed reactor. The scheme of laboratory setup is presented in Fig. 1. The fixed bed reactor was constructed with two stainless steel pipes, external and internal and they were concentric positioned. External pipe was motionless and it was encircled by electrical heaters and placed inside the ceramic insulation. Internal pipe was installed inside the external pipe and was able to move by push. Thanks to it, a biomass sample was supplied to the hot zone of the reactor.

The reactor facility could be divided into three main regions. In the first zone, on the right side, a biomass sample was placed on the moveable pipe and it was prepared for the investigation. In every tested case, 1 gram of biomass was fed into the reactor. Inside pipes, nitrogen (99.9999\% of nitrogen content) was flowing. Rotameter was used to measure the flow rate which had been set to $100 \mathrm{ml} / \mathrm{min}$. In this region also the biomass sample was cooled after pyrolysis up to $80^{\circ} \mathrm{C}$ by a water heat exchanger.

Second area was the heating zone of the fixed bed reactor. In this stage, the temperature of pyrolysis was set and it was equal to: 400,500 and $600{ }^{\circ} \mathrm{C}$. The heat was supplied by electrical heaters. The biomass sample had been fed to the middle stage of the reactor and it was kept for 150 seconds. Wall temperature and sample temperature was measured by thermocouples type $\mathrm{K}$ and they were monitored on the temperature indicator.

Third zone was used to cool a volatile matter which had contained moisture, light - weight gases and primary and secondary tars. Released gases from the biomass sample flowed through the ice bucket where heavy hydrocarbons and steam condensed. In the container, a liquid fraction was collected. In the last part, noncondensable gases were captured in the gas bag.

Uniqueness of this setup was placement of a cold sample to the preheated reactor. It allowed the heat sample quickly from ambient temperature to the reactor temperature with non - linear heating rate.

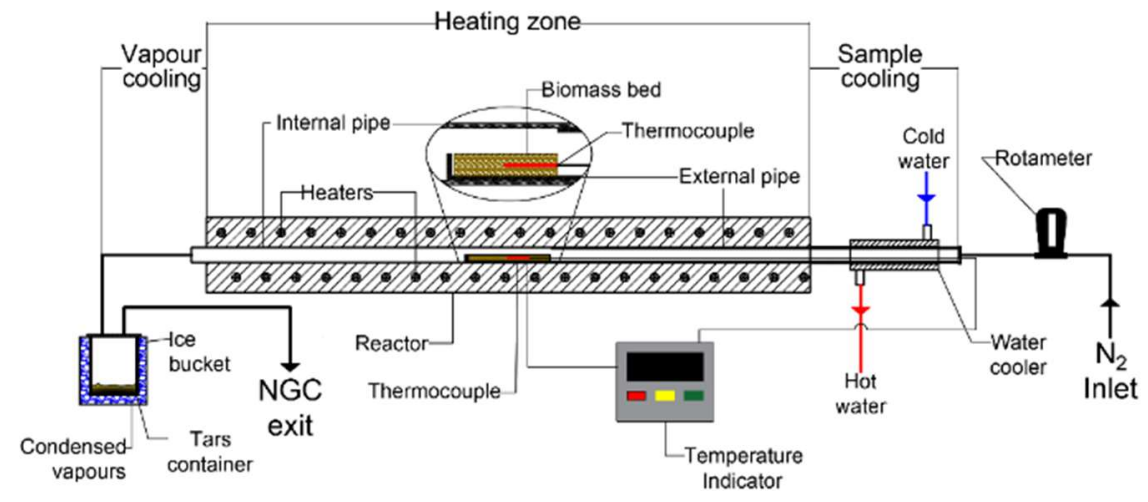

Fig. 1. Laboratory setup of intermediate pyrolysis 


\subsection{Biomass characterization}

Two types of biomasses were selected for the experiments: pine bark and wheat straw. In pretreatment processes, feedstocks were dried under ambient conditions and then were milled and sieved. In the next step, $0.2-0.3 \mathrm{~mm}$ particles were chosen for experiments.

Characterization of selected feedstock was performed via ultimate and proximate analysis. Carbon, hydrogen, nitrogen and sulphur contents had been made by Truspec CHNS 628 Leco analyser. The proximate analysis was performed according to standards: EN ISO 18122:2015 (volatile matter), EN ISO 18134-2:2017 (moisture) and EN ISO 18122:2015 (for ash). Obtained results are presented in Table 2.

Table 2. Ultimate and proximate analysis of pine bark and wheat straw (wt. \%) [17]

\begin{tabular}{|c|c|c|}
\hline Material & $\begin{array}{c}\text { Pine } \\
\text { bark }\end{array}$ & Wheat straw \\
\hline \multicolumn{3}{|c|}{ Ultimate analysis } \\
\hline $\mathbf{C}$ & 48.50 & 43.70 \\
\hline $\mathbf{H}$ & 5.90 & 6.11 \\
\hline $\mathbf{N}$ & 0.17 & 0.52 \\
\hline $\mathbf{S}$ & 0.029 & 0.098 \\
\hline $\mathbf{O}^{\mathrm{a}}$ & 45.53 & 49.57 \\
\hline \multicolumn{3}{|c|}{ Proximate analysis } \\
\hline $\mathbf{M}$ & 10.10 & 7.53 \\
\hline VM & 61.05 & 70.59 \\
\hline Ash & 0.89 & 6.06 \\
\hline FC & 27.97 & 15.82 \\
\hline
\end{tabular}

${ }^{\mathrm{a}} \mathrm{O}$ by difference, ash free

${ }^{\mathrm{b}} \mathrm{FC}($ Fixed Carbon $)=100-\mathrm{M}$ (Moisture $)-\mathrm{VM}($ Volatiles matter) - Ash

The fibre structure was performed via van Soest method [18] to determine contents of hemicellulose, cellulose, lignin and extractives. Results are presented in Table 3.

Table 3. Fibre analysis of pine bark and wheat straw (wt. \%) [17]

\begin{tabular}{|c|c|c|}
\hline Material & $\begin{array}{c}\text { Pine } \\
\text { bark }\end{array}$ & Wheat straw \\
\hline Cellulose & 22.58 & 24.71 \\
\hline Hemicellulose & 5.68 & 32.13 \\
\hline Lignin & 49.20 & 12.64 \\
\hline Extractives & 22.58 & 30.09 \\
\hline
\end{tabular}

\subsection{Products characterization}

Products from intermediate pyrolysis were categorized into three groups: char, condensable vapours and noncondensable gases. Char, liquid fraction and gas phase yields were calculated using equations (1), (2) and (3). The liquid fraction contained condensable elements as primary and secondary tars and moisture.

$$
\text { Yield }_{\text {char }}=\frac{\text { weight of the cha collected }}{\text { weight of biomass sample }} \cdot 100 \%
$$

$$
\begin{aligned}
\text { Yield }_{\text {liquid }} & =\frac{\text { weight of the liquid collected }}{\text { weight of biomass sample }} \cdot 100 \% \\
\text { Yield }_{\text {gas }} & =100 \%-\text { Yield }_{\text {cha }}-\text { Yield }_{\text {liquid }}
\end{aligned}
$$

Carbon, hydrogen and nitrogen contents in char and oil were performed using Truspec CHNS 628 Leco analyser, which had been used previously for ultimate analysis of raw materials. Only an organic fraction of liquid phase was analysed in the ultimate analysis. Aqueous fraction had been separated and it did not be considered in determination of elements content.

Higher heating values (HHV) of char and organic fraction of liquid were calculated according to correlation (4) [19]. This equation is based on the elemental composition of various fuels as raw feedstock, char, oil etc.

$$
\begin{aligned}
& H H V=349.1 \cdot C+1178.3 \cdot H+ \\
& +100.5 \cdot S-103.4 \cdot O-15.1 \cdot N \\
& \quad-21.1 \cdot \text { Ash }
\end{aligned}
$$

\section{$3 \quad$ Results}

\subsection{Yield of products}

Fig. 2 and 3 present yields of products obtained for intermediate pyrolysis of pine bark (Fig. 2) and wheat straw (Fig. 3) at three temperatures.

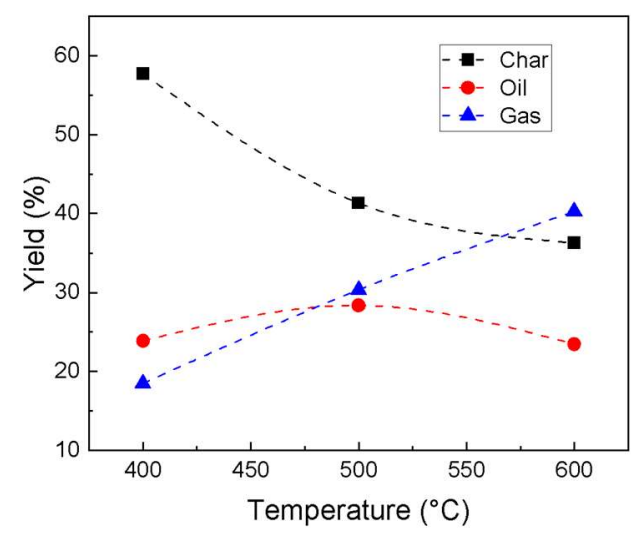

Fig. 2. Yields of products derived from pine bark

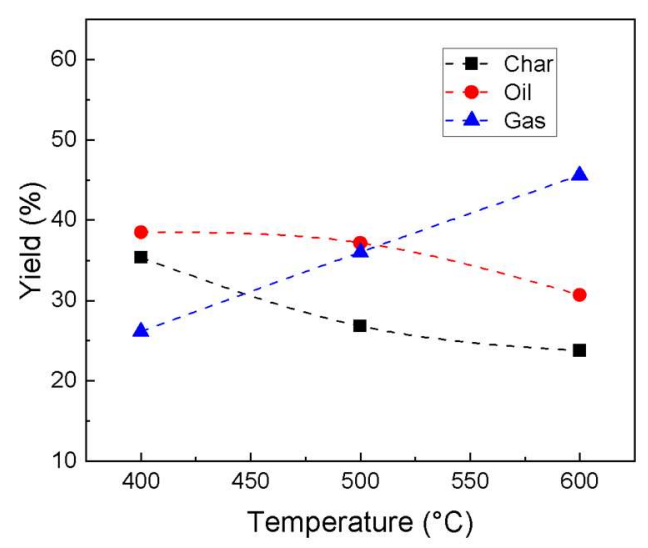

Fig. 3. Yields of products derived from wheat straw 
For both feedstocks, the content of solid residues decreased in function of temperature while yields of non-condensable gases increased. For pine bark, the liquid fraction was the highest at $500{ }^{\circ} \mathrm{C}$. It dropped for wheat straw as temperature increases and the highest production of liquid fraction was obtained at $400{ }^{\circ} \mathrm{C}$, what was $38.5 \%$. At $400{ }^{\circ} \mathrm{C}$, pine bark released the lowest amount of volatiles matter and the solid residue consisted around $57.7 \%$. At the same temperature, wheat straw was able to lose its weight up to $35.4 \%$. It can be observed a balanced proportion of oil and permanent gases for both feedstocks at $500{ }^{\circ} \mathrm{C}$. The amount of oil and gas was around $30 \%$ for both products in case of pine bark while it was $35 \%$ for wheat straw. The concentration of non-condensable gases dominated pyrolysis products at $600{ }^{\circ} \mathrm{C}$ and it was $45.6 \%$ for pine bark and $40.3 \%$ for wheat straw. In both cases higher temperature caused a lower concentration of oil and higher amount of gases. It is due to secondary reaction, where higher temperature destructs primary tars into light-weight gases.

For every temperature, pine bark delivered more yield of char than wheat straw. Pine bark has a higher content of lignin which is the main contributor for char formation [20,21]. Another situation is for wheat straw where extractives and hemicellulose dominate in the structure. These compounds start to pyrolyze at a lower temperature than lignin, which leads to higher amounts of volatiles and lower fraction of solid residue.

The obtained results of product yields received from this intermediate pyrolysis correspond to work [22], where Mohammed et. al analysed intermediate pyrolysis of bambara groundnut shell KARO and EX-SOKOTO in fixed bed reactor at $500,550,600$ and $650{ }^{\circ} \mathrm{C}$ with heating rate equal to $50{ }^{\circ} \mathrm{C} / \mathrm{min}$. Scientists received yields of char, oil and gases respectively 33, 33.3 and $32.4 \%$ at $500^{\circ} \mathrm{C}$ and $29.2,37.1$ and 33.3 at $600^{\circ} \mathrm{C}$ for KARO. For EX-SOKOTO case, char, oil and gas fraction was respectively $39.9,26.2,33.9 \%$ at $500^{\circ} \mathrm{C}$ and $31,32.8$ and $35 \%$ at $600^{\circ} \mathrm{C}$.

In other work, Tinwala et. al [23] made an analysis of intermediate pyrolysis of eight different biomass feedstocks at $500^{\circ} \mathrm{C}$. Range of received yield of char was from 27.5 to $40 \%$, for oil it was from 20.5 to $47.5 \%$ and for gases it was from 24.5 to $40.5 \%$. The yield of each product strictly depended on the used sample.

\subsection{Ultimate analysis of char}

Fig. 4 and 5 present elemental analysis of char obtained from intermediate pyrolysis of pine bark (Fig. 4) and wheat straw (Fig. 5).

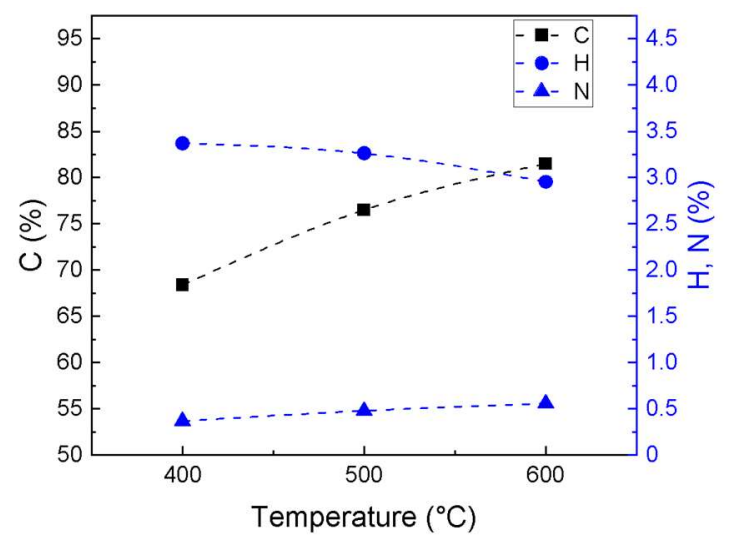

Fig. 4. Ultimate analysis of char derived from pine bark

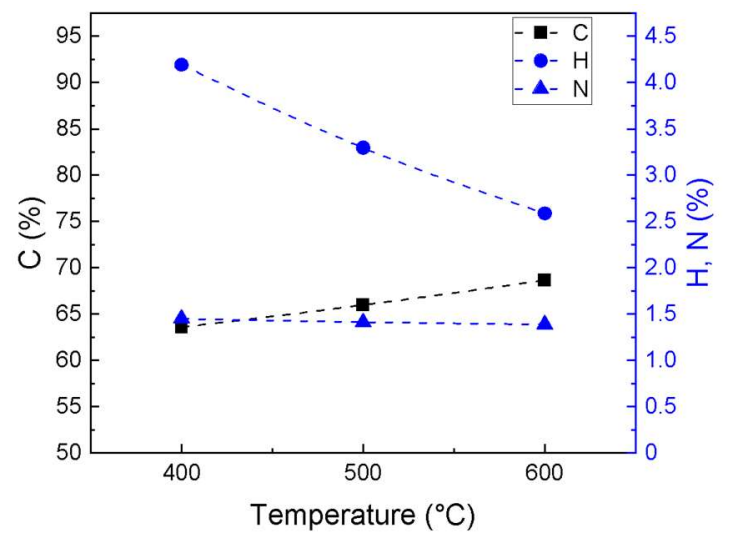

Fig. 5. Ultimate analysis of char derived from wheat straw

In both cases, higher temperature caused higher content of carbon and lower content of hydrogen. Char derived from pine bark increased its carbon content from $68.4 \%$ at $400^{\circ} \mathrm{C}$ to $81.5 \%$ at $600^{\circ} \mathrm{C}$. For wheat straw, the increase of carbon content was lower than for pine bark. In this case, carbon content increased from $63.6 \%$ at $400^{\circ} \mathrm{C}$ to $68.6 \%$ at $600^{\circ} \mathrm{C}$. It proves that pine bark is able to deliver a char which is richer in carbon, which is desirable in solid fuels. The content of hydrogen dropped from 3.4 to $2.9 \%$ for pine bark and from 4.2 to $2.6 \%$ for wheat straw. The amount of nitrogen slightly increased from $0.37 \%$ to $0.56 \%$ for pine bark while for wheat straw it was nearly at the same level equal to $1.4 \%$.

The analysis of quality of derived solid fuels was made by plotting van Krevelen [20] diagram and it is presented in Fig. 6. 


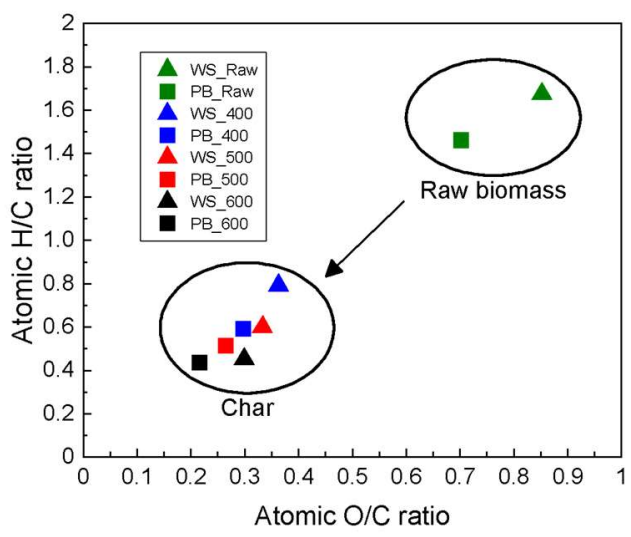

Fig. 6. Van Krevelen diagram for considered solid fuels

The most desirable effect is to lower the oxygen to carbon ratio. It means that solid fuels contain a lower amount of oxygen which is a ballast in solid fuels, because it decreases a higher heating value. On the presented figure 6 it can be observed that for all respected cases, chars had a lower $\mathrm{O} / \mathrm{C}$ ratio than raw feedstocks. It can be noticed that higher temperature caused lower $\mathrm{O} / \mathrm{C}$ ratio and the lowest one was calculated for char derived from pine bark at $600^{\circ} \mathrm{C}$. Also hydrogen to carbon ratio was the lowest for this fuel. It can be concluded that char from intermediate pyrolysis of pine bark at $600^{\circ} \mathrm{C}$ could be comparable to bituminous coal which usually has carbon content in the range from 78 to $86 \%$ [24].

\subsection{Ultimate analysis of oil}

Fig. 7 and 8 present the ultimate analysis of organic fraction of collected liquid phase.

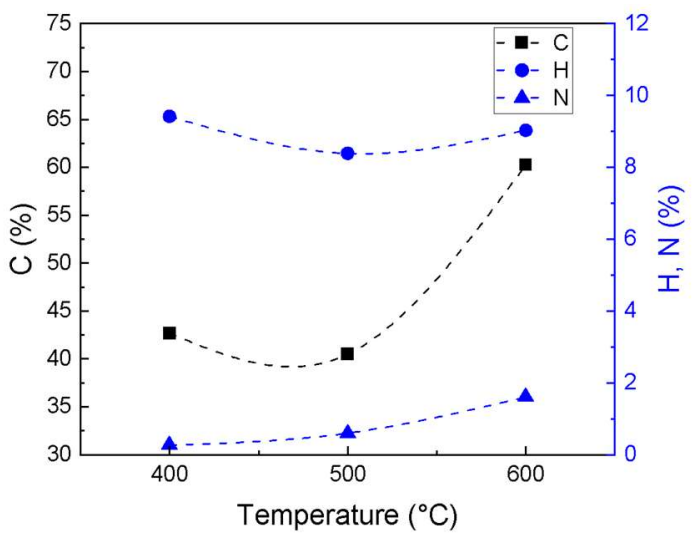

Fig. 7. Ultimate analysis of oil derived from pine bark

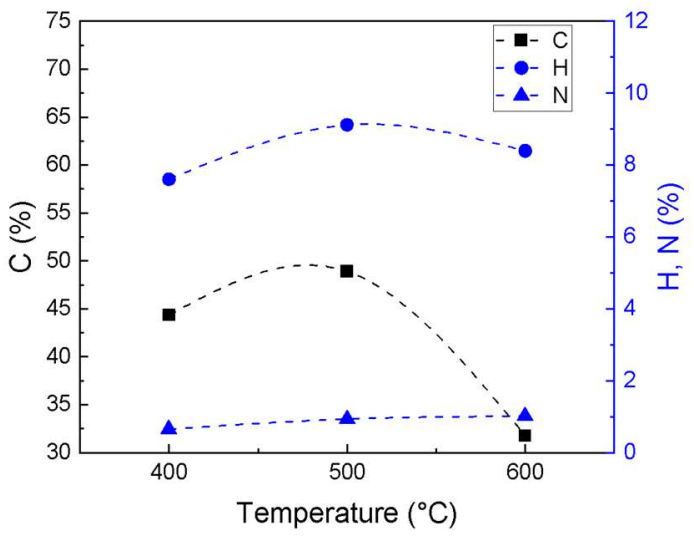

Fig. 8 Ultimate analysis of oil derived from wheat straw

The highest content of carbon was observed for oil obtained from pine bark at $600^{\circ} \mathrm{C}$ and it was $60.3 \%$. For this feedstock, lowering temperature caused the decrease of carbon in the organic structure. The Reverse situation was for oil from wheat straw. The lowest amount of carbon was measured at $600^{\circ} \mathrm{C}$ it was around $31.8 \%$ which was nearly twice times lower than for pine bark. The highest concentration of hydrogen delivered oil from pine bark at $400^{\circ} \mathrm{C}$ and it was $9.4 \%$. The increasing temperature caused lowering hydrogen content. At $500^{\circ} \mathrm{C}$ wheat straw supplied an oil fraction which contained the highest quantity of carbon and hydrogen these were respectively $48.9 \%$ and $9.1 \%$. For both samples the nitrogen content in oil fraction increased with temperature increasing.

\subsection{Higher heating value of products}

Tables 4 and 5 present results of higher heating value (HHV) of obtained products and raw materials. The Eq. 4, ultimate and proximate analysis were used to calculate this amount.

Table 4. Higher heating values of feedstocks and chars

\begin{tabular}{|c|c|c|}
\hline \multirow{2}{*}{$\begin{array}{c}\text { Temperature } \\
\left({ }^{\circ} \mathbf{C}\right)\end{array}$} & \multicolumn{2}{|c|}{$\begin{array}{c}\text { HHV of char } \\
(\mathbf{M J} / \mathbf{k g})\end{array}$} \\
\cline { 2 - 3 } & Pine bark & $\begin{array}{c}\text { Wheat } \\
\text { straw }\end{array}$ \\
\hline 400 & 25.00 & 23.79 \\
\hline 500 & 27.72 & 23.72 \\
\hline 600 & 29.47 & 24.02 \\
\hline Feedstocks & 19.16 & 17.28 \\
\hline
\end{tabular}


Table 5. Higher heating values of oils

\begin{tabular}{|c|c|c|}
\hline \multirow{2}{*}{$\begin{array}{c}\text { Temperature } \\
\left({ }^{\circ} \mathbf{C}\right)\end{array}$} & \multicolumn{2}{|c|}{$\begin{array}{c}\text { HHV of oil (MJ/kg) } \\
\text { (organic fraction) }\end{array}$} \\
\cline { 2 - 3 } & $\begin{array}{c}\text { Pine } \\
\text { bark }\end{array}$ & $\begin{array}{c}\text { Wheat } \\
\text { straw }\end{array}$ \\
\hline 400 & 25.96 & 24.40 \\
\hline 500 & 22.22 & 27.78 \\
\hline 600 & 31.62 & 20.93 \\
\hline
\end{tabular}

The most calorific product was oil from pine bark obtained at $600^{\circ} \mathrm{C}$ which had an HHV of $31.62 \mathrm{MJ} / \mathrm{kg}$. Also in these conditions, pine bark supplied the most energetic char with HHV equal to $29.47 \mathrm{MJ} / \mathrm{kg}$. For pine bark and wheat straw, decreasing temperature caused lowering higher heating value of char. For wheat straw, the most calorific oil was obtained at $500^{\circ} \mathrm{C}$ and for other cases, higher heating values were lower and the smallest one was calculated for $600^{\circ} \mathrm{C}$. All received products had the HHV higher than primary feedstocks.

\section{Conclusions}

In this paper, results of the intermediate pyrolysis of pine bark and wheat straw at three temperatures were presented. The analysis of received products was made. Results showed that for both feedstocks, higher temperature promoted a higher amount of non condensable gases while char fraction was decreasing. As temperature increased liquid fraction lowered because secondary reactions started to dominate at higher temperatures. The maximal yield of oil could be obtained from wheat straw at $400^{\circ} \mathrm{C}$ which was $38.5 \%$. The ultimate analysis of char proved that higher content of carbon of char could be obtained at higher temperatures, especially for pine bark where the carbon content increased from $68.4 \%$ at $400^{\circ} \mathrm{C}$ to $81.5 \%$ at $600^{\circ} \mathrm{C}$. For wheat straw this growth was from $63.6 \%$ at $400^{\circ} \mathrm{C}$ to $68.6 \%$ at $600^{\circ} \mathrm{C}$. The hydrogen concentration lowered as temperature increased for both materials.

Char from pine bark obtained at $600{ }^{\circ} \mathrm{C}$ had the best quality which had been proved by the lowest $\mathrm{O} / \mathrm{C}$ and $\mathrm{H} / \mathrm{C}$ ratios respectively 0.22 and 0.44 . At this temperature, the organic fraction of liquid phase from pine bark had the highest concentration of carbon. These two products were the most energetic fuels and their higher heating values were $31.62 \mathrm{MJ} / \mathrm{kg}$ for oil and $29.47 \mathrm{MJ} / \mathrm{kg}$ for char.

This work was financially supported by the Ministry of Science and Higher Education, Poland [grants: AGH no. 16.16.110.663].

\section{References}

1. Directive 2009/28/EC, Directive 2009/28/EC of the European Parliament and of the Council of 23 April 2009 on the Promotion of the Use of Energy from Renewable Sources and Amending and Subsequently Repealing Directives 2001/77/EC and 2003/30/EC (2009)

2. https://www.trade.gov/country-commercialguides/poland-energy, access online 23.04.2021

3. https://www.lasy.gov.pl/pl/nasze-lasy/polskielasy, access online 23.04.2021

4. Renewable energy in Poland, Flanders Investment\&Trade, June 2019

5. M. Tripathi, J. N. Sahu, and P. Ganesan, Renew. Sustain. Energy Rev. 55, 467 (2016)

6. S. Al Arni, Renew. Energy 124, 197 (2018)

7. G. Greco, C. Di Stasi, F. Rego, B. González, and J. J. Manyà, Appl. Energy 279, 115842 (2020)

8. F. Cerciello, B. Apicella, C. Russo, L. Cortese, and O. Senneca, Fuel 287, 119604 (2021)

9. M. Sharifzadeh, M. Sadeqzadeh, M. Guo, T. N. Borhani, N. V. S. N. Murthy Konda, M. C. Garcia, L. Wang, J. Hallett, and N. Shah, Prog. Energy Combust. Sci. 71, 1 (2019)

10. M. Buffi, A. M. Rizzo, L. Pari, and D. Chiaramonti, Int. J. Oil, Gas Coal Technol. 17, 355 (2018)

11. J. Waluyo, I. G. B. N. Makertihartha, and H. Susanto, in (2018), p. 020026

12. S.-H. Jung and J.-S. Kim, J. Anal. Appl. Pyrolysis 107, 116 (2014)

13. J. Santos, M. Ouadi, H. Jahangiri, and A. Hornung, Food Bioprod. Process. 114, 23 (2019)

14. K. Lazdovica, V. Kampars, L. Liepina, and M. Vilka, J. Anal. Appl. Pyrolysis 124, 1 (2017)

15. Z. Wang, K. G. Burra, M. Zhang, X. Li, M. Policella, T. Lei, and A. K. Gupta, Fuel 274, (2020)

16. A. Güngör, S. Önenç, S. Uçar, and J. Yanik, J. Anal. Appl. Pyrolysis 97, 39 (2012)

17. W. Jerzak, A. Bieniek, and A. Magdziarz, Int. J. Hydrogen Energy (2021)

18. P. J. Van Soest, J. Assoc. Off. Anal. Chem. 73, 491 (1990)

19. S. A. Channiwala and P. P. Parikh, Fuel 81, 1051 (2002)

20. P. Basu, Biomass Gasification, Pyrolysis and Torrefaction: Practical Design and Theory (Elsevier Inc., 2013)

21. T. Ding, S. Li, J. Xie, W. Song, J. Yao, and W. Lin, Chem. Eng. Technol. 35, 2170 (2012)

22. I. Y. Mohammed, Y. A. Abakr, M. Musa, S. Yusup, A. Singh, and F. K. Kazi, J. Clean. Prod. 139, 717 (2016)

23. F. Tinwala, P. Mohanty, S. Parmar, A. Patel, and K. K. Pant, Bioresour. Technol. 188, 258 (2015)

24. L. D. Smoot, Pulverized-Coal Combust. Gasif. 123 (1979) 